\title{
What pragmatics can do for wh-movement: Extractions from that-complements in German*
}

\author{
Sonja Müller
}

\begin{abstract}
Constraints on wh-movement have long been a central issue for questions of locality in syntax and have a long research tradition in various paradigms and models. Defining domains which are transparent (or opaque) for long wh-movement - also known as extraction - is only one of the many topics which fall under the heading of movement restrictions. This paper is concerned with extractions from a particular domain, namely that-complement clauses in German, which provide a challenge to every syntactic theory as one and the same structural domain can be either transparent or opaque depending on the embedding matrix verb. The paper investigates what a semantic solution might look like and provides arguments for the assumption that a pragmatic principle is most suitable for an explanation.
\end{abstract}

\section{Introduction}

It has been known at least since Ross' (1967) island constraints that long wh-movement, also known as extraction, can only occur from certain domains. The data in (1) to (3) show that German neither allows movement from subjects (cf. (1)), nor from adjuncts (cf. (2)) nor relative clauses (cf. (3)).

(1) *Worüber hat [ein Buch Paul beeindruckt?

What.about has a book habout Paul impressed

'A book about what impressed Paul?' (intended reading)

*Was putzt Maria die Wohnung, [während Hans was liest]?

What cleans Mary the flat while Hans what reads

'Mary is cleaning the flat while Hans is reading what?' (intended reading)

*Was kenne ich die Einbrecher, [die was geklaut haben]?

What know I the burglars who stolen have

'I know the burglars who stole what?' (intended reading)

But as (4) illustrates, German does allow movement from complement clauses, here an infinitival complement clause.

(4) Wen hast du versprochen [wen zu küssen]?

Who have you promised whe to kiss

'Who did you promise to kiss whe'?

For decades, extraction domains have mainly been described in terms of syntactic categories. However, the topic has also been looked at from different perspectives, such as information

\footnotetext{
* I am grateful to Jürgen Lenerz, Horst Lohnstein, Astrid Rothe, Volker Struckmeier and Verena Vogt for comments and suggestions on this paper.
} 
structure, semantics, pragmatics and language processing ${ }^{1}$ because the data suggest that syntax alone cannot explain the restrictions. This is exactly the point where this piece of work comes in. Pairs of sentences such as (5) (i) and (ii) illustrate that the acceptability of the extraction construction depends on the matrix verb so that (i) is preferable to (ii).

Wen glaubt /sagt /wünscht Peter sich, [dass Maria getroffen hat]? Who believes /says /wishes Peter REFL that Mary who met has 'Who does Peter believe/say that Mary met?' $>^{2}$

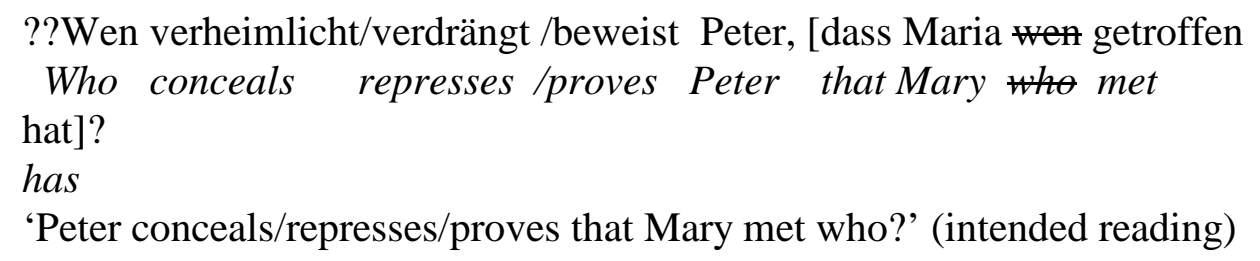

If a verb such as glauben (believe), sagen (say) or (sich) wünschen (wish) constitutes the matrix clause, extraction is fine. If the matrix verb is verheimlichen (conceal), verdrängen (repress) or beweisen (prove), the structure is degraded.

In this paper, the phenomenon of bridge verbs (as illustrated in (5)) is seen as providing evidence for the assumption that non-structural factors can restrict wh-movement. As the extraction occurs from complements in all cases and the sentences only differ in their matrix verbs, it stands to reason that an explanation should rest on a semantic analysis of good and bad extraction verbs.

Although such a procedure seems to point at a semantic explanation, it is the aim of this paper to argue that a pragmatic constraint is most suitable to account for the data. The paper is organised as follows. In section 2, it is argued that syntax (more specifically phase theory) cannot be considered the ruling factor for the phenomenon under discussion. Section 3 analyses the verbs involved semantically and sketches what a semantic constraint could look like by carrying over assumptions originally developed for the interaction of verbal mood and question formation in German. Section 4 provides evidence for the assumption that pragmatic rather than semantic factors constrain the constructions by referring to the distribution of modal particles and a more finely grained analysis of erothetic illocutionary force. The paper is not meant to provide a solution to the puzzle presented in (5), but merely aims at ruling out the other modules, namely syntax and semantics, and motivating a future pragmatic solution (cf. Müller (2010) for a pragmatic explanation).

\section{A syntactic solution?}

This first section serves the purpose of arguing that a purely syntactic analysis cannot do justice to the locality phenomenon at issue. Although there are syntactic accounts which try to incorporate the phenomenon of bridge verbs (e.g. Pütz (1975), Cattell (1978), Fanselow (1987), Grewendorf (1988), Cinque (1990), Hegarty (1990), Müller (1995), Müller/Sternefeld

\footnotetext{
${ }^{1}$ Cf. e.g. Chomsky (1986), Rizzi (1990), Nunes/Uriagereka (2000), Erteschik-Shir (1973, 1997, 2007), Szabolcsi/Zwarts (1993), Abrusán (2007), Kluender (1998), to name but a few.

2 'Better than'
} 
(1995)), this section only looks at the most recent account concerned with locality phenomena within minimalist syntax, namely phase theory (cf. Chomsky (2000, 2001, 2004, 2008).

The basic idea of this theory is that syntactic structure is not sent to the linguistic interfaces PF and LF after having been fully completed at the end of the derivation (the implicit assumption prevalent in Government and Binding Theory (Chomsky (1981)). Rather, parts of the generated structure are already 'put aside' in the course of a derivation. Consequently, spell-out does not apply only once in a derivation, but after certain defined and phonologically and semantically motivated sections. Within Chomsky's approach, CP and $v^{*} \mathrm{P}$ constitute phases. After the projection of a phase has been completed, the phase's domain, i.e. the phase head's complement, is simultaneously sent to the PF- and LF-interface and is thus rendered inaccessible to further syntactic operations such as movement. This procedure finds its formulation in the Phase Impenetrability Condition (PIC) (cf. (6)).

\section{Phase Impenetrability Condition (PIC)}

In phase $\alpha$ with head $\mathrm{H}$, the domain of $\mathrm{H}$ [=complement of $\mathrm{H}]$ is not accessible to operations outside $\alpha$ [=HP], only $\mathrm{H}$ and its edge [ $=\mathrm{H}$ plus any/all of its specifiers $]$ are accessible to such operations.

cf. Chomsky (2000:108)

(information in brackets by S. M.)

(7) illustrates the configuration described in (6). HP is a phase whose complement ZP becomes opaque for movement/agree processes. The phase head $\mathrm{H}^{\circ}$ and the Spec HP-position (edge), however, are still accessible to the syntactic component in (7).

(7)
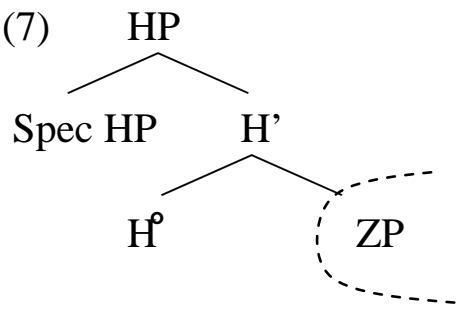

Going through the derivation of (8) in (9) shows that no problems arise for the derivation at any point.

$$
\begin{aligned}
& \text { ??Wen verursacht Peter, dass der Chef entlässt? } \\
& \text { Who causes Peter that the boss fires } \\
& \text { 'Peter causes the boss to fire who?' (intended reading) }
\end{aligned}
$$

Once the lower $v \mathrm{P}$ is completed, the wh-element has to leave its position and move to the $v \mathrm{P}$ 's edge (triggered by an EPP in $v^{\circ}$ ). The VP is spelled out, but the moved wh-element is still available for syntactic operations, and the derivation continues up to the next phasal projection, the lower CP. In order not to be spelled out as part of the TP, the wh-element needs to move to the phase edge, namely Spec CP (again triggered by an EPP in $\mathrm{C}^{\circ}$ ). The same 'escape hatch movements' are repeated when the upper $\nu \mathrm{P}$ and $\mathrm{CP}$ are projected. 
(9)

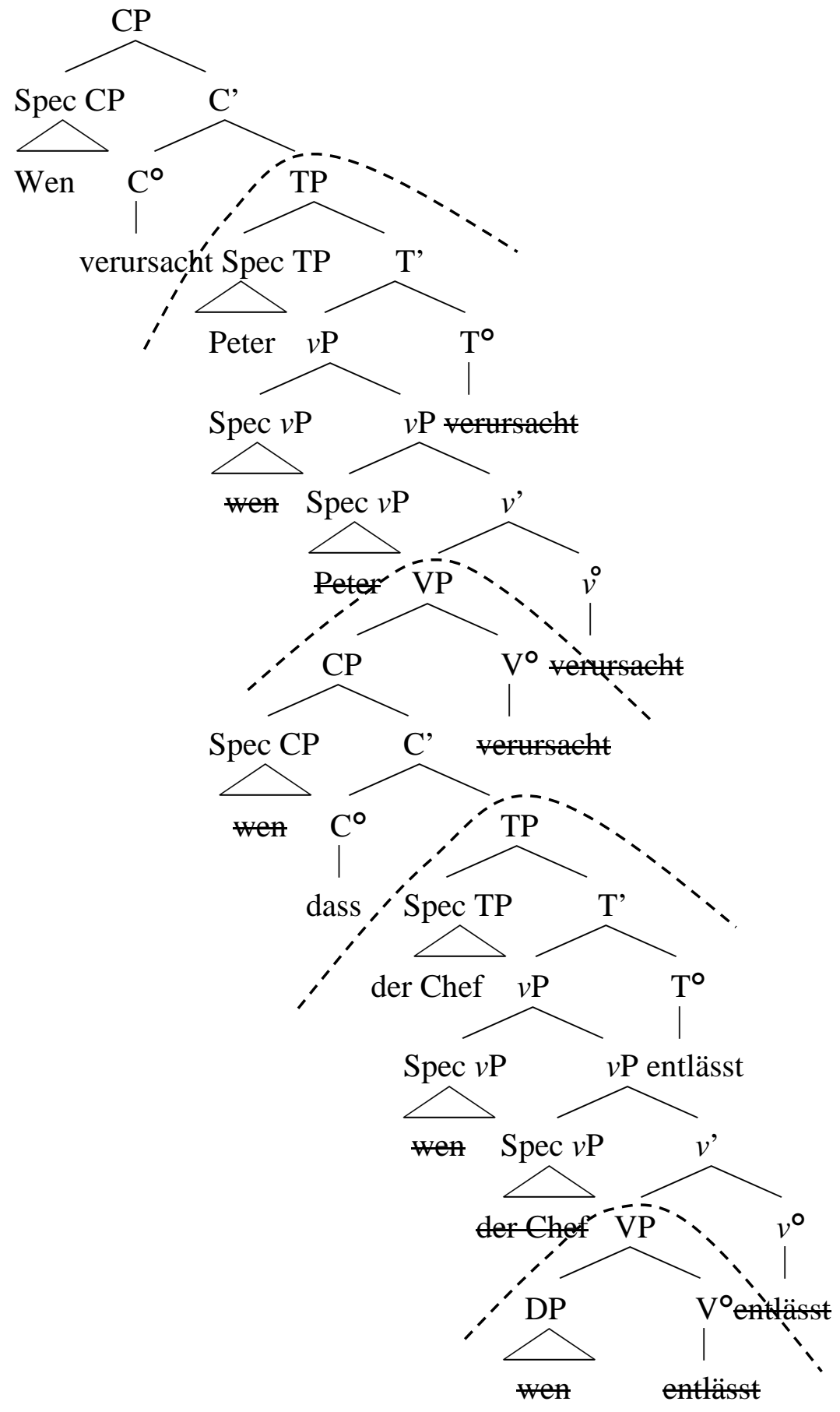

The derivation nicely illustrates the need for cyclic wh-movement which is now motivated by the extractee having to leave the phases' complements if it wants to stay in the active derivation. However, it does not suggest any reason for why the construction in (8) should be sensitive to the subtype of verb that embeds the lower CP: All verbs in (5) are, arguably, verbs that allow for the same types of complements. Can semantic differences account for the differences in (5)? 
3. A semantic solution?

3.1 Verb classes

Although the differences might be subtle in some particular cases, questions in which the matrix verbs grouped in (10) occur differ in acceptability from the sentences in which the verbs grouped in (11) occur. ${ }^{4}$ For example, verbs which allow extraction from their complements are verbs of saying (cf. (10) (i)), verbs of meaning (cf. (10) (ii)), fiction predicates (cf. (10) (iii)) and verbs which express wishes (cf. (10) (iv)). Verbs which do not allow extraction are factive (cf. (11) (i)) and implicative verbs (cf. (11) (ii)).

(10) (i) verba dicendi: e.g. sagen (say), behaupten (state), berichten (report)

(ii) verba putandi: e.g. denken (think), glauben (believe), finden (find), vermuten (assume)

(iii) fiction predicates: e.g. vorstellen (imagine), träumen (dream), sich einbilden (imagine)

(iv) volitive verbs: e.g. wollen (want), wünschen (wish), befehlen (command), bitten (aks for)

(11) (i) factive verbs: e.g. ignorieren (ignore), implizieren (imply), verdrängen (repress), verheimlichen (conceal)

(ii) implicative verbs: e.g. verursachen (cause), verhindern (prevent), beweisen (prove)

Therefore, the constructions in (12) are considerably better than the constructions in (13).

(12) (i) Wen sagt Peter, dass Maria eingeladen hat?

Who says Peter that Mary invited has

'Who does Peter say that Mary invited?'

(ii) Wen glaubt Peter, dass Maria eingeladen hat?

Who believes Peter that Mary invited has

'Who does Peter believe that Mary invited?'

(iii) Wen träumt Peter, dass Maria eingeladen hat?

Who dreams Peter that Mary invited has

'Who does Peter dream that Mary invited?'

(iv) Wen will Peter, dass Maria einlädt?

Who wants Peter that Mary invites

'Who does Peter want for Mary to invite?'

(13) (i) ??Wen verheimlicht Peter, dass Maria eingeladen hat?

Who conceals Peter that Mary invited has

'Peter conceals that Mary invited who?' (intended reading)

\footnotetext{
${ }^{4}$ The verb classes grouped in (10) and (11) are only an illustrative subset of the verbs tested in Müller (2010). The reader be referred to this piece of work for a more detailed analysis.
} 
(ii) ??Wen ignoriert Peter, dass Maria eingeladen hat?

Who ignores Peter that Mary invited has

'Peter ignores the fact that Mary invited who?' (intended reading)

(iii) ??Wen beweist Peter, dass Maria eingeladen hat?

Who proves Peter that Mary invited has

'Peter proves that Mary invited who?' (intended reading)

As already mentioned in the introduction, a solution to the puzzle at issue should rest on a semantic property that the verbs in (12) have and which the verbs in (13) lack (or the other way round).

Without relying on any particular semantic theory here, it can be seen from the adequate and inadequate continuations in (14) and (15) that the verbs in (12) and (13) clearly differ from each other as far as truth-value assignment to the proposition expressed in their complement is concerned.

(14) Peter says/believes/dreams that Mary invited John, ...

(i) but Mary did not invite John.

(ii) and indeed, Mary invited John.

(15) Peter conceals/proves that Mary invited John, \#but Mary did not invite John.

Whereas the sentences in (14) can be uttered felicitously by a speaker without being committed to the subordinate clause's truth, this is not possible with the sentences in (15). When choosing a factive verb such as conceal or an implicative verb such as prove in the matrix of a complex sentence such as (15), the truth of the embedded proposition cannot be denied. This phenomenon is known as a factive verb's presupposition and, respectively, an implicative verb's implication and is to be understood in analogy to possibly more familiar presuppositions such as (16) or implications such as (17).

(16) (i) Peter stopped drinking.

(ii) Peter used to drink.

(17) (i) Peter is singing loudly.

(ii) Peter is singing.

In pre-theoretic terms, presuppositions as well as implications can be regarded as inferences that e.g. lexical items such as stop, sentences such as (17) (i) or verbs such as conceal or prove trigger and which are obviously not triggered in the case of predicates such as believe, dream or wish. There is no restriction as to whether a matrix subject's beliefs, dreams or wishes are actually true or false. A proposition someone believes can be true, but it does not have to be. On the contrary, one cannot conceal or prove an issue without that issue being true. Although there are definitely differences between presuppositions and implications, and therefore, between factive and implicative verbs ${ }^{5}$, both verb classes make bad extraction verbs and thus,

${ }^{5}$ Cf. Karttunen (1971). E.g. implications in constrast to presuppositions get cancelled under negation (cf. (i) vs. (ii)).

(i) Peter does not conceal that Mary loves John. -> Mary loves John.

(ii) Peter does not prove that Mary loves John. -/> Mary loves John. 
they clearly differ from the fairly acceptable extraction verbs in that the truth value assignment to their complement proposition has already taken place when the truth value of the whole sentence is evaluated, whereas the truth value of the complement proposition of the latter is still open. ${ }^{6}$

\subsection{Truth value assignment as a precondition for question formation}

The sentence mood theory by Lohnstein $(2000,2007)$ might serve as a guideline for a semantic solution to the phenomenon discussed. Part of Lohnstein's theory is an account of why question formation in root clauses is not compatible with all verbal moods in German. Limiting the depiction of this phenomenon to constituent questions here, (18) and (19) illustrate that question formation results in ungrammaticality when the verb carries imperative (cf. (18) (i)) or present subjunctive (cf. (18) (ii)) verbal morphology, whereas it leads to perfect well-formedness in the case of the indicative (cf. (19) (i)) or past subjunctive (cf. (19) (ii)).

(i) *Was iss', Peter?

What eat.IMP Peter

(ii) *Was esse Peter?

What eat.SUBJ.PRS Peter

(19) (i) Was isst Peter?

What eats Peter

'What does Peter eat?'

(ii) Was äße Peter?

What eat.SUBJ.PST Peter

'What would Peter eat?'

A further observation within Lohnstein's account concerns the adequate and inadequate continuations of the dialogues in (20) to (23). They suggest that only propositions containing an indicative or past subjunctive finite verb allow truth value assignment.

(20) Hans: Peter, iss' eine Torte!

Peter, eat.IMP a flan

'Eat a flan, Peter!'

Fritz: \#Nein, das ist nicht wahr./Ja, das ist wahr.

No that is not true yes that is true

'No, that's not right./Yes, that's right.'

(21) Hans: Peter esse eine Torte.

Peter eats.SBJ.PRS a flan

'Peter eat a flan.'

Fritz: \#Nein, das ist nicht wahr./Ja, das ist wahr.

No that is not true yes that is true

'No, that's not right./Yes, that's right.'

\footnotetext{
6 The negative influence of factive verbs on extractions from that-complements has also been integrated into purely structural accounts of the phenomenon (cf. Cinque (1990), Rizzi (1990), Manzini (1992)).
} 
Hans: Peter isst eine Torte.

Peter eats a flan

'Peter is eating a flan.'

Fritz: Nein, das ist nicht wahr./Ja, das ist wahr.

No that is not true yes that is true

'No, that's not right./Yes, that's right.'

Hans: Peter äße eine Torte.
Peter eats.SUBJ.PST $a$ flan
'Peter would eat a flan,'

Fritz: Nein, das ist nicht wahr./Ja, das ist wahr. No that is not true yes that is true

'No, that's not right./Yes, that's right.'

As exactly those verbal moods that do not allow question formation do not allow truth value assignment either, Lohnstein ascribes the two observations to the same principle. His explanation rests on the assumption that verbal moods restrict the evaluation domain of a proposition to certain classes of worlds. These classes can be understood as conversational backgrounds in the sense of Kratzer (1978, 1981, 1991).

Kratzer employs the notion of conversational backgrounds to account for the indeterminacy of sentences such as (24). The speaker expresses the possibility of Peter coming to the party. However, this assumption can be based e.g. on what the speaker knows (cf. (25) (i)) or on what Peter is allowed to do (cf. (25) (ii)).

(24) Peter can come to the party.

(25) (i) As far as we know, it is possible that Peter comes to the party.

(ii) As far as what is allowed, it is possible that Peter comes to the party.

Kratzer accounts for theses interpretations by assuming that a proposition which contains a modal verb can be evaluated with respect to different backgrounds. A conversational background is understood as a set of propositions which represent what is e.g. known in the actual world ([epistemic background] in the example above, it might contain propositions such as Peter is in town., Peter has the time to come.) or what is allowed ([deontic background] Peter is invited., His wife does not insist on him staying at home.). Assuming that propositions are associated with the worlds in which they are true, different (sub)sets of worlds are taken into consideration to decide on the truth/falsity of the sentence in (24). Under the interpretation in (25) (i), the sentence in (24) is true in the actual world if there is at least one world among the worlds in which all the propositions constituting the epistemic background are true, in which Peter is coming to the party. The same applies to the worlds in which the propositions which stand for what is allowed in the actual world are true. The basic idea of this part of Kratzer's theory is that conversational backgrounds determine the evaluation domain of sentences such as (24), i.e. that only a subset of all possible worlds is taken into consideration when calculating their truth value.

In his semantic analysis of verbal mood, Lohnstein assumes two main backgrounds: an epistemic background which contains all the things from past and present that can be known and a factive background which contains mere facts. ${ }^{7} \mathrm{He}$ argues that indicative and past

\footnotetext{
${ }^{7}$ Lohnstein actually assumes a third background (the realistic background) which presents the intersection
} 
subjunctive mood restrict a proposition's evaluation domain to the epistemic background, whereas propositions with present subjunctive and imperative verbs can only be evaluated with respect to the factive background. The classification of verbal moods and backgrounds is motivated by the observation in (20) to (23) and, furthermore, by the discourse functions that sentences in the respective verbal moods can fulfil.

Relevant data illustrating Lohnstein's point with respect to the discourse functions of utterances in the respective verbal moods can be found in (26) to (29).

(i) $\quad \mathrm{n}$ sei eine Primzahl.

$n$ be a prime number

,n be a prime number.'

(ii) Kommissar: Angenommen Jack Foley habe die Bank überfallen, ...

Commissar: Assumed Jack Foley have. SBJ.PRS the bank robbed, ...

'Commissar: Assuming, Jack Foley robbed the bank, ...'

(iii) Man nehme Eier, Mehl und Milch.

One takes.SBJ.PRS eggs, flour and milk

'Take eggs, flour and milk.'

(27) (i) Bring' den Müll 'raus!

Take.IMP the trash out

'Take out the trash!'

(ii) Zieh' besser deine Jacke an!

Put.IMP better your jacket on

'You had better put on your jacket!'

(iii) Hau' bloß ab!

Lop PRT off

'Hit the road!'

(28) Astrid fährt mit dem Rad zur Uni.

Astrid drives with the bike to.the uni

'Astrid goes to uni by bike.'

(29) Astrid führe mit dem Rad zur Uni (, wenn es nicht regnen würde).

Astrid drives.SBJ.PST with the bike to.the uni (, if it not rain would).

'Astrid would go to uni by bike (, if it wasn't raining).

Whereas (28) and (29) provide descriptions of what the actual world or another world (differing from the actual one at least in the proposition explicitly expressed in the conditional clause) is like, (26) and (27) change the world directly by introducing mathematical premises or fictive assumptions or express the wish to change it by setting up the steps to be taken when wanting to bake a cake (cf. (26) (iii)) or by telling the addressee what to do (cf. (27)).

As a mere description of a world can be said to match the state of affairs or not, propositions in the indicative and past subjunctive are assumed to be evaluated with respect to what a speaker can know (epistemic background). Propositions expressed by utterances which change the world directly or which introduce a change of the actual world that somehow

between the other two domains and contains the known facts. However, its role in the approach is not relevant for the discussion here and is, therefore, left out in what follows. 
depends on the addressee's reaction cannot be evaluated against a background of things that can be known by the speaker. The property Lohnstein (2000:110) attributes to the uses in (26) and (27) is what he calls "fictive and prospective factivity" ("fiktive und prospektive Faktizität"). Propositions containing imperative or present subjunctive verbal mood are evaluated with respect to the factive background which is constituted by propositions representing actual or future facts.

Deriving different evaluation domains for the verbal moods from the discourse functions in (26) to (29) ties in nicely with the observations from (20) to (23) that denial and acceptance of the propositions expressed are suitable reactions when the target contains a past subjunctive or indicative finite verb, but not when the verb carries present subjunctive or imperative verbal mood. Lohnstein's reasoning goes as follows: Facts are neither true nor false, they are just what they are, namely facts. Consequently, saying about a proposition that has to be evaluated in the factive domain that it is true or false is inadequate (cf. (20), (21)). Epistemic contents, i.e. propositions a speaker can know, on the other hand, can be said to be evaluated as true or false by the speaker. Therefore, the dialogues in (22) and (23) are felicitous.

Lohnstein's account of the ill-formed questions is modelled within Partition Semantics (cf. Groenendijk/Stokhof (1984, 1997), Higginbotham/May (1981), Higginbotham (1991, 1996)). This theory roughly states that a wh-question partitions the space of possibilities, i.e. all possible worlds, into mutually exclusive cells, each containing the set of worlds in which one possible complete answer to the question is true (cf. (30)).

What is Peter eating?, $\mathrm{D}=\{$ pizza, salad $\}$

(ii)

\begin{tabular}{|l|l|}
\hline 1 & 2 \\
$\begin{array}{l}\text { Peter is eating } \\
\text { pizza and salad. }\end{array}$ & $\begin{array}{l}\text { Peter is eating } \\
\text { pizza, but no } \\
\text { salad. }\end{array}$ \\
\hline 3 & 4 \\
$\begin{array}{l}\text { Peter is eating } \\
\text { no pizza, but } \\
\text { salad. }\end{array}$ & $\begin{array}{l}\text { Peter is neither } \\
\text { eating pizza, nor } \\
\text { salad. }\end{array}$ \\
\hline
\end{tabular}

A question like (30) (i) therefore partitions the set of all worlds into four subsets. In each of those subsets another state of affairs with respect to Peter eating something is obtained. As the four cells exclude each other, each answer to the question is true in only one set of worlds and false in all the other ones. ${ }^{8}$

As the question of truth or falsity is not under discussion when speaking about facts, a

\footnotetext{
${ }^{8}$ The strong exhaustivity ascribed to the answers within this approach which is called into question by one of the anonymous reviewers has indeed been under discussion in the literature on question semantics. Another account which allows only weak exhaustivity of the answers is Karttunen (1977). Heim (1994) offers an account which incorporates strong exhaustivity into Karttunen's semantics for questions. See Hagstrom (2003) and Lohnstein (2000) for a discussion of the different accounts.
} 
partition as in (30) (ii) cannot be induced in case the proposition is evaluated against the factive background. Facts do not divide logical space into cells in which they are true and cells in which they are false. As epistemic content is open to truth value assignment, there are worlds in which a proposition which is evaluated against the epistemic background is true and worlds where it is false. By assuming the two conversational backgrounds and assuming that verbal mood restricts the evaluation of propositions to either of the two, Lohnstein derives the impossibility of truth value assignment to propositions in the present subjunctive and imperative as well as the impossibility to form a wh-question in that case.

As for the extraction problem at hand, one could apply Lohnstein's approach by arguing that the embedded propositions are evaluated against the factive background in the degraded cases. As was illustrated in 3.1, in the bad extraction cases (repeated for convenience in (31) and (32)), the embedded proposition is presupposed or implied.

$$
\text { ??Wen verheimlicht Peter, dass Maria liebt?, D = }\{\text { Hans, Paul }\}
$$

Who conceals Peter that Mary loves

'Peter conceals that Mary loves who?' (intended reading)

$$
\text { Peter conceals that Mary loves John. -> Mary loves John. }
$$

(i) ??Wen verursacht Peter, dass der Chef entlässt?, D $=\{$ Hans, Paul $\}$

Who causes Peter that the boss fires

'Peter causes the boss to fire who?' (intended reading)

(ii) Peter verursacht, dass der Chef einen Mitarbeiter entlässt. -> Der Chef entlässt

Peter causes that the boss an assistant fires The boss fires einen Mitarbeiter.

an assistant.

The embedded proposition's truth value is not under discussion any more, but the positive truth value has already been assigned. There is no way to utter (31) (ii) and (32) (ii), assuming at the same time that it is not clear whether the embedded state of affairs obtains or not.

In this sense, asking for the precise form of a state of affairs being caused or concealed results in dividing the logical space of things which are caused/concealed by Peter into cells in which different states of affairs are possible for the embedded issue (cf. (33)).

\begin{tabular}{|c|c|}
\hline Peter conceals tha & \\
\hline $\begin{array}{l}1 \\
\text { Mary loves John } \\
\text { and Paul. }\end{array}$ & $\begin{array}{l}2 \\
\text { Mary loves } \\
\text { John, but does } \\
\text { not love Paul. }\end{array}$ \\
\hline $\begin{array}{l}3 \\
\text { Mary does not } \\
\text { love John, but } \\
\text { loves Paul. }\end{array}$ & $\begin{array}{l}4 \\
\text { Mary neither } \\
\text { loves John nor } \\
\text { Paul. }\end{array}$ \\
\hline
\end{tabular}


As the embedded issue which is already assigned a truth value, however, is not under debate anymore at the point where the question is asked, and considered a fact, the partition in (33) cannot sensibly be induced. The ill-formedness of (31) (i) and (32) (i) could therefore be derived in parallel to Lohnstein's account of ungrammatical questions containing verbs in the imperative or present subjunctive. In both cases, the evaluation domain of the proposition which is partitioned is the factive background. Looking at an acceptable construction (cf. (34)) reveals that the parallel to Lohnstein's observations can be maintained.

Wen glaubt Peter, dass Maria eingeladen hat?

Who believes Peter that Mary invited has

'Who does Peter believe that Mary invited?'

(ii) Peter believes that Mary invited John, but Mary did not invite John/and indeed, Mary invited John.

In (34), the embedded proposition's truth value is not fixed yet, therefore, the exact nature of the embedded state of affair is still under discussion. As in the case of epistemic contents conveyed by indicative and past subjunctive, as long as a proposition's truth value is still undecided in discourse or can be under discussion at all, partitioning and, therefore, question formation, can apply.

The above argument has shown that Lohnstein's theory of verbal mood can be used to explain the difference between good and bad extractions from that-complement clauses insofar as both phenomena seem sensitive to the factivity of syntactic structures. ${ }^{9}$

\section{Why pragmatics?}

Section 3 argues for a semantic account of good and bad extraction verbs. However, further data point in yet another direction, namely pragmatics.

\subsection{Modal particles in the embedded clause}

The first piece of evidence for the assumption that a pragmatic principle constrains the extraction constructions comes from the occurrence of modal particles in the embedded clause the wh-element moves from.

It is argued that modal particles express the speaker's attitude towards the utterance (cf. e.g. Weydt (1969), Bublitz (1978), Doherty (1985), Thurmair (1989)). As the English paraphrase for (35) shows, the particle ja e.g. expresses that speaker and hearer already know about the sentence's content.

\footnotetext{
${ }^{9}$ One anonymous reviewer conjectures that the semantic difference between good and bad extraction verbs might be one of a more "abstract meaning" in the case of worse extraction verbs. However, such an analysis had to rest on clear criteria with respect to when the meaning of a verb is more or less abstract. The argumentation equals Erteschik-Shir's (1973) concept of semantic weight, Kluender's (1991) referential specificity or Featherston's (2004) notion of plausible complex predicates and, therefore, falls under the same points of criticism: The application of all of these concepts as well as that of abstract meaning - which intuitively seem plausible properties - presuppose a good theory of (lexical) decomposition which identifies the components constituting the above concepts to different degrees. The accounts mentioned do not provide such theories. Truth value assignment, however, is a precise property which can be tested and which can be used to make predictions on good and bad extraction verbs.
} 
Maria heiratet Hans ja.

Mary marries Hans PRT

'As we both know, Mary is going to marry John.'

The particle wohl on the other hand expresses uncertainty on part of the speaker (cf. (36)).

(36) Maria heiratet Hans wohl.

Mary marries Hans PRT

'It seems that Mary is going to marry Hans.'

Modal particles may also occur in embedded clauses. In this case, there is an ambiguity as to whether they express the speaker's or the matrix subject's attitude. ${ }^{10}$

(37) Peter sagt, dass Maria Hans ja heiratet.

Peter says that Mary Hans PRT marries

'Peter assumes that his addressee already knows about Mary marrying Hans.'

or

'The speaker assumes that his addressee knows about Mary marrying Hans.'

(38) Peter sagt, dass Maria Hans wohl heiratet.

Peter says that Mary Hans PRT marries

'Peter is uncertain about Mary marrying Hans.'

or

'The speaker is uncertain about Mary marrying Hans.'

(37) can either mean that, in the original utterance situation, Peter assumes that his audience already knows about Mary marrying Hans or that in the current utterance situation, the speaker assumes the addressee to know about Mary marrying Hans. Similarly, (38) is ambiguous as to whether Peter or the speaker is uncertain about Mary marrying Hans. As the examples in (39) and (40) illustrate, the context can disambiguate the two readings (illustrated here for (37)).

(39) Situation: Fritz is eavesdropping on Peter and Maren.

Karl: Can you understand anything at all?

Fritz: Yes, wait. It's exciting! They are speaking about Mary's plans to build a house.

Karl: What are they saying?

Fritz: Maren doesn't understand Mary's plans. Und Peter sagt, dass Maria Hans ja heiratet. In two weeks time. And Maren says that's clear as they (i.e. Maren and Peter) are both invited to the wedding. And she says that that wouldn't be a reason for her to build a house so quickly!

Karl: Glaring! Did you know that the two are going to be married? I didn't know that!

Fritz: No, that's completely new to me, too. But Peter and Maren both knew it. Hey

\footnotetext{
${ }^{10}$ It is far from clear what happens when modal particles occur in that-complement clauses. Works which deal with this phenomenon make incompatible assumptions as to the matrix verbs that allow the embedding at all and the 'anchor' of the particle (speaker vs. matrix subject) (cf. e.g. Kwon (2005:46), Thurmair (1989:75), Coniglio (2007:115)). Those open questions left aside, I assume that modal particles can occur in the embedded clause in the examples looked at here and that both anchorings are possible here as well.
} 
man, we should rather go before they'll notice we're here.

(40) Situation: Karl is on the phone to Peter. Fritz wants to know what he's saying during a long passage by Peter.

Fritz: Anything new?

Karl: No, not really. (Bored by the call)

Fritz: But what does he say? He will be speaking about something, won't he?

Karl: Well. Peter sagt (z.B.), dass Maria Hans ja heiratet.

Fritz: But we've known that for a long time!

Karl: Yes, that's why I'm bored... But Peter doesn't know that we already know this, but I had better not tell him.

In (39), the context is supposed to show that the embedded clause's content is known to the original discourse's participants (i.e. Maren and Peter), in (40), however, to the current speaker and his addressee (i.e. Fritz and Karl). The contexts are moreover meant to convey that the use of the particle cannot be assigned to the speaker (i.e. Karl) in (39) nor to the matrix subject (i.e. Peter) in (40).

For the following argument, it is important that the modal particle in the embedded clause can in principle express the speaker's attitude. This applies to ja as well as to wohl. The decisive difference between these two particles is that $j a$ expresses that speaker as well as hearer know about the embedded issue or at least the speaker expresses that s/he knows about it and assumes the addressee to know about it, too. Whereas the reported ambiguity can be observed in the constructions in (37) and (38), it vanishes in the case of $j a$ when an element gets extracted from the complement clause. For (41) - interpreted as an information-seeking question by the speaker -, this means that the reading relating the modal particle to the speaker is not possible anymore. $J a$ can only refer to the matrix subject and one even has to force this reading for the sentence to be acceptable at all.

(41) Wen sagt Peter, dass Maria ja heiratet?

Who says Peter that Mary PRT marries

However, there is no comparable problem for (42). The uncertainty induced by the modal particle wohl can still be attributed to the matrix subject or to the speaker.

(42) Wen sagt Peter, dass Maria wohl heiratet?

Who says Peter that Marry PRT marries

If modal particles in the subordinate clause influence extractions from this domain and if the demarcation line between semantics and pragmatics runs along truth functional vs. non-truth functional meaning as is traditionally assumed (cf. e.g. Kadmon (2001:1)), pragmatics seems to win over semantics as modal particles do not contribute to the truth functional meaning of a sentence (cf. (43)). The sentences in (43) are true in all the worlds in which Uncle Hans used to work for the navy. Expressing the speaker's attitude (certainty (cf. (43) (ii) vs. uncertainty (cf. (43) (iii))) does not influence the conditions under which the sentences are true.

(43) (i) Onkel Hans war bei der Marine.

Uncle Hans was at the navy

'Uncle Hans used to work for the navy.' 
(ii) Onkel Hans war ja bei der Marine.

Uncle Hans was PRT at the navy

'As we both know, uncle Hans used to work for the navy.'

(iii) Onkel Hans war wohl bei der Marine.

Uncle Hans was PRT at the navy

'Seemingly, uncle Hans used to work for the navy.'

\subsection{A more finely grained analysis of erothetic illocutionary force}

Further support for the assumption that a pragmatic constraint restricts extractions from thatcomplements in German comes from a deeper analysis of the question illocution. According to Searle's conditions for the illocutionary type 'question', constituent questions standardly serve the purpose of expressing a cognitive deficit on part of the speaker which s/he wishes to be removed by the hearer:

(44) Preparatory condition:

Sincerity condition:

Essential condition:
S does not know 'the answer', i.e. [...] does not know the information needed to complete the proposition truly $[\ldots]$.

$\mathrm{S}$ wants this information.

Counts as an attempt to elicit this information from $\mathrm{H}$.

Searle (1974:66)

As can be seen from Searle's comment (cf. Searle (1974:66)), his description in (44) targets one particular type of question, namely an information seeking question. The intention of this illocutionary type can, however, vary. Variation can be reached by certain lexical means (e.g. insertion of modal particles, intonation, focus) or by providing respective contexts. E.g. by using the particle doch or the combination doch gleich, the speaker signals that s/he is asking for information which s/he in fact knows, but has temporarily forgotten. Franck (1988:181ff.) calls this the "erinnernde doch" ('remembering doch'), Luukko-Vinchenzo (1989:30) calls it the speaker's attempt to remove his/her loss of memory. Consequently, (45) (i) gets the reading that the sports club used to be known to the speaker as was the wife's name in (45) (ii).

(i) Nun, wie hieß doch der Sportverein, in dem du warst früher?

Well, how named PRT the sports club in the you were earlier

'Well, what was the name of your former sports club again?'

Kwon (2005:91)

(ii) Wie hieß doch (gleich) seine erste Frau?

How named PRT (PRT) his first wife

'What was his first wife's name again?'

Thurmair (1989:269)

Moreover, inserting the modal particles schon or wohl or the combination of schon + a modal verb + a past participle in a wh-question leads to a rhetorical interpretation of the question. Asking (46) (i), (ii) or (iii) carries the expectation that an affirmative answer to the question which contains the unique referent of the wh-pronoun is easily available for the addressee and known to the speaker. 
(46) (i) Was kann ich damit schon gemeint haben?

What can I therewith PRT meant have

'What can I have meant by that, after all?'

Kwon (2005:103)

(ii) Uwe: Was hast du denn heute gemacht?

What have you PRT today made

'What did you do today then?'

Maria: Na, was werd ich schon gemacht haben? (Gearbeitet natürlich.)

INT what will I PRT made have (worked of.course)

'Well, what will I obviously have done today?' (Work of course.)

(iii) Uli: Von wem ist denn der Brief?

Thurmair (1989:154)

By whom is PRT the letter

'Who sent the letter, then?'

Nina: Na, von wem wohl? (Von der Bank natürlich.)

INT by whom PRT (By the bank of.course.)

'Well, from whom can it be? (From the bank, of course.)'

Thurmair (1989:145)

The insertion of certain particles can also serve the purpose of expressing the need for an urgent answer to the question. Kwon (2005) and Thurmair (1989) provide the examples in (47) and (48) to show that blo $\beta$ and nur strengthen the question act and direct the speaker's full interest to it.

(47) Wo kommt nur auf einmal dieser dicke, fette Hase her?

Where comes PRT at once this big fat rabbitfrom

'Where does this big fat rabbit come from suddenly?'

Kwon (2005:132)

(48) “Donnerwetter!" hörte Jaga ihn murmeln, "einfach fabelhaft!" Voller Bewunderung

Thunderstorm heard Jaga him mumble simply fabulous Full.of admiration

starrte er sie an. "Wo hast du das bloß gelernt?", wollte er wissen.

stared he her on Where have you that PRT learnt wanted he to.know

"Gosh!" Jaga heard him mumble, "just fabulous!” Full of admiration, he starred at her.

"Where have you learned that, after all?" he wanted to know.

Thurmair (1989:241)

In both cases, the speaker is not asking in passing, but has a very strong interest in the answer to the question.

As far as extraction constructions are concerned, it can be shown that changing a question's intention has an impact on the acceptability of the constructions. The comparison of the isolated extraction construction in (49) with the same construction under the occurrence of the particles doch gleich in (50) shows that inserting these particles improves the question.

(49) ??Wen impliziert die Aussage, dass der Chef entlässt?

Who implies the statement that the boss fires 
'Who does the statement imply that the boss will fire?'

(50) Peter: I can only remember that several members of staff were on the verge of being fired. And then there was this silly statement from the boss which told us in a roundabout way who would have to go. I do remember the strange atmosphere.

Hm, aber wen implizierte die Aussage doch gleich, dass der Chef entlässt?

INT, but who implied the statement PRT PRT that the boss fires

'Well, but who was it again for whom the statement implied that the boss would fire him?'

The same phenomenon can be observed with a rhetorical reading of the extraction construction (cf. (51)).

(51) (i) Naja, das ist doch klar. Wer hier nicht ordentlich arbeitet, ist doch bekannt. INT that is PRT clear. Who here not neatly works is PRT known

Also: Wen kann die Aussage schon impliziert haben, dass der Chef entlässt? So: Who can the statement PRT implied have that the boss fires?

Frau Meier natürlich.

Ms Meier naturally.

'Umm, that's clear though. Who doesn't work properly is known. So: Who can the statement have implied that the boss will fire after all? Ms Meier of course.'

(ii) Peter: ??Wen impliziert die Aussage, dass der Chef entlässt?

Who implies the statement that the boss fires

'Who does the statement imply that the boss will fire?'

Fritz: Na, wen impliziert die Aussage schon, dass der Chef entlässt?

INT who implies the statement PRT that the boss fires.

'Hey, who does the statement imply that the boss will fire, after all?

Mich natürlich. Einer ist ja immer der Dumme.

Me of.course. Someone is PRT always the fool

Of course it's me. Someone has to be the loser, after all.'

(iii) Wen impliziert die Aussage wohl, dass der Chef entlässt? (Dich natürlich!) Who implies the statement PRT that the boss fires (You of.course!) 'Who does the statement imply that the boss will fire, after all? (Of course it's you!)'

Whereas the insertion of doch gleich, wohl and schon seems to lead to an improvement in acceptability, the occurrence of blo $\beta$ and nur has the opposite effect or at least does not affect the sentences positively (cf. (52)). The acceptability of (52) as well as (49) is rather low. 
??Wen impliziert die Aussage nur/bloß, dass der Chef entlässt?

Who implies the statement PRT/PRT that the boss fires

'Tell me: Who is it whom the boss will fire?'

Since different question intentions as illustrated here are a matter of context (e.g. speaker's knowledge/attitude/wishes) and therefore of pragmatics rather than syntax (wh-movement applies in all cases) or semantics (there is still the referent's gap to be filled, i.e. partitioning of logical space is induced), these empirical facts provide evidence for the hypothesis pursued in this paper that a pragmatic constraint seems best suited to regulate the acceptability of the extraction constructions.

\section{Conclusion}

This paper has investigated a particular movement phenomenon which seems to resist explanation by any syntactic locality principle. As shown in section 2, no syntactic violation occurs when going through the derivation of a bad extraction construction. As the different degrees of acceptability ascribed to the extraction constructions can be traced back to the occurrence of the matrix verbs involved which clearly differ in their semantic properties with respect to truth value assignment (cf. 3.1), looking for a semantic constraint seems suggestive at first glance. This approach is even supported by seemingly parallel factors being at work in question formations in root clauses with changing verbal mood (cf. 3.2). However, further data (the occurrence of modal particles in the embedded clause and different question intentions) seem to point at pragmatics rather than semantics being the decisive module for ruling out unacceptable extractions from that-complement clauses. The overall aim of this paper was to provide arguments for the assumption that the principle ruling out unacceptable extraction constructions can be attributed to the pragmatic module. ${ }^{11}$ Core-grammar, in this case, does not seem to define the pertinent constraint in wh-movement. Rather, the pragmatic factors which induce the differences in acceptability will have to be defined more precisely (cf. Müller (2010) for such an account).

\footnotetext{
${ }^{11}$ The anonymous reviewers conjecture that this conclusion might not be valid or might not be the only explanation for the matrix verbs' influence. One reviewer suggests that this influence might be due to more or less complex syllable structures. On the one hand, many bad extraction verbs (e.g. ver-schwit-zen (forget), be-wei-sen (prove), ver-ur-sa-chen (cause)) are indeed more complex than good extraction verbs (e.g. sa-gen (say), glau-ben (believe), wol-len (want)) as far as e.g. the number of syllables is concerned. Featherston (2004:187) mentions that good extraction verbs tend to be short across languages. Although bad extraction verbs which are short are indeed hard to find, there are many examples of good extraction verbs which are equally complex in comparison to the bad extraction verbs mentioned above (e.g. an-neh-men (assume), ver-mu-ten (conjecture), er-zäh-len (tell), sich ein-bil-den (imagine)). Above that, reference to syllable structure does not seem to be a plausible explanation in the light of the influence of modal particles embedded under the same matrix verb (cf. 4.1) and the contextual influence of the question's intention (cf. 4.2) as the syllable structure is kept constant in both cases. The same applies to the suggestion made by the reviewers that frequency might be the decisive factor. To explain the data in 4.1 and 4.2 (where the matrix verb is not changed), one would have to argue that the combination of the matrix verb say and the particle $j a$ is less frequent than the combination of say and the particle wohl. Similarly, one would have to argue that e.g. a rhetorical question containing the matrix verb imply is more frequent than an information seeking question containing the same verb. These conclusions do not seem very plausible to me.
} 
References

Abrusán, M. (2007): Contradiction and Grammar: The Case of Weak Islands. Ph.D. Diss., MIT. Accesible via: http://sites.google.com/site/martaabrusan/. 22.10.2009.

Bublitz, W. (1978): Ausdrucksweisen der Sprechereinstellung im Deutschen und Englischen: Untersuchung zur Syntax, Semantik und Pragmatik der deutschen Modalpartikeln und Vergewisserungsfragen und ihrer englischen Entsprechungen. Tübingen.

Cattell, R. (1978): On the Source of Interrogative Adverbs. In: Language 54. pp. 61-77.

Chomsky, N. (1981): Lectures on Government and Binding. Amsterdam.

Chomsky, N. (1986): Barriers. Linguistic Inquiry Monograph 13. Cambridge, Massachusetts.

Chomsky, N. (2000): Minimalist Inquiries: The Framework. In: Martin, R./Michaels, D./Uriagereka, J. (eds.) Step by Step: Essays on Minimalist Syntax in Honor of Howard Lasnik. Cambridge, Massachusetts. pp. 89-155.

Chomsky, N. (2001): Derivation by Phase. In: Kenstowicz, M. (ed.): Ken Hale. A Life in Language. Cambridge, Massachusetts. pp. 1-52.

Chomsky, N. (2004): Beyond Explanatory Adequacy. In: Belletti. A. (ed.): Structures and Beyond: The Cartography of Syntactic Structures, Vol. 3. Oxford. pp. 104-131.

Chomsky, N. (2008): On Phases. In: Freidin, R./Otero, C./Zubizarreta, M. L. (eds.): Foundational Issues in Linguistic Theory. Cambridge, Massachuesetts. pp. 133-166.

Cinque, G. (1990): Types of A'-Dependencies. Cambridge, Massachusetts.

Coniglio, M. (2007): German Modal Particles in Root and Embedded Clauses. University of Venice Working Papers in Linguistics 17. Venice. pp. 109-141.

Doherty, M. (1985): Epistemische Bedeutung. Berlin.

Erteschik-Shir, N. (1973): On the Nature of Island Constraints. Ph.D. Diss., MIT (reproduced by the Indiana University Linguistics Club, Bloomington, IN).

Erteschik-Shir, N. (1997): The Dynamics of focus structure. Cambridge.

Erteschik-Shir, N. (2007): Information Structure. The Syntax-Discourse Interface. Oxford.

Fanselow, G. (1987): Konfigurationalität. Tübingen.

Featherston, S. (2004): Bridge Verbs and V2 Verbs: The Same Thing in Spades? In: Zeitschrift für Sprachwissenschaft 23/2. pp. 181-210.

Farkas, D. (2003): Assertion, Belief and Mood Choice, presented at ESSLLI, Conditional and Unconditional Modality Workshop. Vienna.

Grewendorf, G. (1988): Aspekte der deutschen Syntax. Tübingen.

Groenendijk, J./Stokhof, M. (1984): On the Semantics of Questions and the Pragmatics of Answers. In: Landman, F./Veltman, F. (eds.): Varieties of Formal Semantics. Dordrecht. pp. 143-170.

Groenendijk, J./Stokhof, M. (1997): Questions. In: ter Meulen, A. et al. (eds.): Handbook of Logic and Language. Amsterdam. pp. 1055-1124.

Hagstrom, P. (2003): What Questions Mean. In: Glot International Vol.7 7/8. pp. 188-201.

Hegarty, M. (1990): On Adjunct Extractions from Complements. MIT Working Papers in Linguistics. pp. 101-124.

Heim, I. (1994): Interrogative Semantics and Karttunen's Semantics for Know. In: Buchalla, R./Mittwoch, A. (eds.): The Proceedings of the Ninth Annual Conference and the Workshop on the Discourse of the Israel Association for Theoretical Linguistics. Jerusalem. pp. 128-144.

Higginbotham, J./May, R. (1981): Questions, Quantifiers, and Crossing. In: Linguistic Review 1. pp. 41-80. 
Higginbotham, J. (1991): Interrogatives I. MIT Working papers in linguistics 14. pp. 47-76.

Higginbotham, J. (1996): The Semantics of Questions. In: Lappin, S. (ed.): The Handbook of Contemporary Semantic Theory. Oxford. pp. 361-383.

Kadmon, N. (2001): Formal Pragmatics. Oxford.

Karttunen, L. (1971): Implicative Verbs. In: Language 47. pp. 340-358.

Karttunen, L. (1977): Syntax and Semantics of Questions. In: Linguistics and Philosophy 1. pp. 3-44.

Kluender, R. (1998): On the Distinction between Strong and Weak Islands: A Processing Perspective. In: Syntax and Semantics 29. The Limits of Syntax. pp. 241-279.

Kratzer, A. (1978): Semantik der Rede. Kontexttheorie, Modalwörter, Konditionalsätze. Königstein.

Kratzer, A. (1981): The Notional Category of Modality. In: Eikmeyer, H./Rieser, E. (eds.): Words, Worlds, and Contexts. New Approaches in World Semantics. Berlin.

Kratzer, A. (1991): Modality. In: von Stechow, A./Wunderlich, D. (eds.): Semantik: Ein internationales Handbuch der zeitgenössischen Forschung. Berlin. pp. 639-650.

Kwon, M.-J. (2005): Modalpartikeln und Satzmodus. Untersuchungen zur Syntax, Semantik und Pragmatik der deutschen Modalpartikeln. Dissertation, München. Accessed via: Deutsche Nationalbibliothek http://deposit.ddb.de/cgi-bin/dokserv?idn=978873653. 19.4.2009.

Lohnstein, H. (2000): Satzmodus - kompositionell. Zur Parametrisierung der Modusphrase im Deutschen. Berlin.

Lohnstein, H. (2007): On Clause Types and Sentential Force. In: Linguistische Berichte 209. pp. 63-86.

Luukko-Vinchenzo, L. (1988): Formen von Fragen und Funktionen von Fragesätzen. Eine deutsch-finnische kontrastive Studie unter besonderer Berücksichtigung der Intonation. Tübingen.

Manzini, R. (1992): Locality: A Theory and some of its Empirical Consequences. Cambridge, Massachusetts.

Müller, G. (1995): A-bar Syntax. A Study of Movement Types. Berlin.

Müller, S. (2010): (Un)informativität und Grammatik. Extraktion aus dass-/ob- und wKomplementsätzen im Deutschen. Dissertation, Universität zu Köln.

Müller, G./Sternefeld, W. (1995): Extraction, Lexical Variation, and the Theory of Barriers. In: Egli, U. et al. (eds.): Lexical Knowledge in the Organization of Language. Amsterdam/ Philadelphia. pp. 35-81.

Nunes, J./Uriagereka, J. (2000): Cyclicity and Extraction Domains. In: Syntax 3/1. pp. 20-43.

Pütz, H. (1975): Über die Syntax der Pronominalform ,es' im modernen Deutsch. Studien zur deutschen Grammatik 3. Tübingen.

Rizzi, L. (1990): Relativized Minimality. Linguistic Inquiry Monographs 16. Cambridge, Massachusetts/London, England.

Ross, J. R. (1967): Constraints on Variables in Syntax. Massachusetts: PhD-dissertation.

Searle, J.R. (1974): Speech Acts. An Essay in the Philosophy of Language. London.

Szabolcsi, A./Zwarts, F. (1993): Weak Islands and an Algebraic Semantics for Scope Taking. In: Natural Language Semantics 1. pp. 235-285.

Thurmair, M. (1989): Modalpartikeln und ihre Kombinationen. Tübingen.

Weydt, H. (1969): Abtönungspartikel: Die deutschen Modalwörter und ihre französischen Entsprechungen. Bad Homburg v.d.H./Berlin/Zürich. 